\title{
Provocation and Control Over the Commission of a Crime: Significance and Correlation
}

\author{
Larysa Arkusha ${ }^{[0000-0002-0422-6416]}$, Oleksandr Torbas * [0000-0002-1465-4238] \\ National University "Odesa Law Academy", Odesa, Ukraine \\ *torbas.oleksandr@gmail.com
}

\begin{abstract}
Provocation (in a broad sense) must be identified as a set of measures based on the application of the method of psychological (manipulative) influence on the life of an individual (or groups) in order to achieve appropriate goal. A provocation over the commission a crime is an action (or inaction) of law enforcement agencies against an individual (or group of persons) in order to influence their decision to commit a crime, provided that the previously mentioned person (persons) did not intend to do so. In contrast to the provocation, control over its commission could be applied in the presence of following conditions: 1) the crime in any case would be committed regardless of the intervention of law enforcement agencies or undercover officers (agents); 2) law enforcement agencies became aware of the likelihood of committing a crime after the intent of the person who plans to commit it; 3) passive role of law enforcement officers or undercover officers (agents) in committing a crime; 4) strict documentary recording of all actions conducted by law enforcement agencies. In order to increase the level of efficiency of covert employees (agents) activities to separate control over the commission of a crime from provocation, it is necessary to set strict rules for their possible actions and the conditions of their use in combating specific manifestations of crime. It was established that activities of all law enforcement agencies of Ukraine require unification of instructions for undercover officers (agents), in compliance with the Law of Ukraine "On State Secrets".
\end{abstract}

Keywords: provocation; control over the commission of a crime, challenge, classification, law enforcement activities, crime, undercover employee (agent).

\section{INTRODUCTION}

Everyone has encountered provocation at least once in their life. This can be a provocative attack by management (or subordinate) with an intension to take appropriate action depending on your endurance and upbringing. It can be a "cascade" of news in the media in order to artificially create public opinion, which than can be used for different purposes [1].

This term has been used in the last ten years in various senses, however, mostly to achieve a manipulative goal as part of the relevant political rhetoric. Thus, in 2008 the word "provocation" was mentioned in 35,604 reports in different media, and in 2018 there were 41,1028 such reports [2]. Politicians, in the absence of other arguments, explain their actions (or inaction) by "provocation" in in its various manifestations. Also, provocation is conditionally called a "conflictogenic form of interaction", according to different goals, views, and so on [3].
"Provocation" from Latin translates as "challenge". It must be noted that provocation can significantly change emphasis according to situation. It can be used both for destruction and for creation [4], be a reason for criminal activities in different spheres: economic, medical, cyber [5: 6: 7; 8] etc. However, historically there has been a negative public attitude towards the essence of provocation, so public rejection and condemnation are caused by the actions of a person who is called a "provocateur" by the media.

After analysing media sources, scientific opinions, as well as their own life experience, it is possible to propose a classification of provocations on the following grounds:

- depending on the field of application: medicine; law enforcement [9]; education [10] and science; media sphere; military sphere; policy area; economics etc.; 
- by subject of application: political figure; journalist; serviceman; investigator (employee of operational units); psychologist; teacher etc.;

- depending on the purpose of application: for diagnosis; for the sake of competition; to destabilize the situation in the region (country); to mislead the enemy (during a military operation); as a method of competition; to expose a hidden crime at the stage of its preparation, commission or concealment; to obtain evidence of preparation or commission of a crime etc.;

- depending on the awareness of the provocation by the subject of application: open or covert provocation;

- by situation: provocation in artificially created conditions; provocation using real conditions without making changes to the environment.

This classification is mostly indicative, however, confirms that provocation is a fairly common phenomenon, and its use in the vocabulary of law enforcement agencies, as well as media in explaining the essence of certain methods and actions of covert investigative activities, may negatively affect perception of such measures by society.

\section{METHODOLOGY}

This research was performed using general scientific and special methods taking into account the direction of research. The comparative legal method and the method of structural-functional analysis were used in in the analysis of current criminal procedure legislation in Ukraine, ECtHR decisions, as well as the results of judicial and law enforcement agencies activities. The method of secondary analysis allowed us to explore the existing scientific views on the concept of "provocation". The synergetic method allowed us to substantiate the need to apply certain provisions of the current Criminal Procedural Code in Ukraine in order to prevent and investigate certain manifestations of crime.

\section{ANALYSIS OF RECENT RESEARCH}

Problems of possible provocation in law enforcement agencies activities arise during the application of such covert investigative (search) action as control over the commission of a crime (Article 271 of the Criminal Procedural Code of Ukraine), which could be conducted as a controlled delivery, controlled and operational procurement, special investigative experiment and simulation of the crime.

The criminal procedure legislation of Ukraine does not contain a clear distinction between control over the commission of a crime and provocation. In Part 3 of Article 271 of the Criminal Procedural Code of Ukraine legislator stated that during the preparation and conduction of such actions it's prohibited to provoke (incite) a person to commit this crime in order to further expose it, help person to commit a crime he would not have committed if the investigator did not interfere, or for the same purpose to influence his/her behaviour by violence, threats, blackmail. Evidence obtained in this way cannot be used in criminal proceedings. Thus, legislator obliges to refrain from provocation before committing a crime, while formulating only a general understanding of provocation and control.

In this case, it should be emphasized that the Criminal Code of Ukraine provides criminal liability for provocation of bribery (Article 370 of the Criminal Code of Ukraine) - "actions of an official to incite a person to offer, promise or provide improper benefit or accept an offer, promise or such benefit to then expose the person who offered, promised, improperly benefited or accepted the offer, promise or received such benefit". The presence of Article 370 of the Criminal Code of Ukraine significantly increases the importance of distinguishing provocation from control over the commission of a crime, because a person suspected of receiving an illegal benefit may become a victim in one criminal proceedings.

In the decision of the European Court of Human Rights "Ramanauskas v. Lithuania" it was stated that provocation by the police occurs in cases where law enforcement officers or persons acting on their behalf are not limited to investigating criminal activity mostly passively, but influence, incite to commit a crime, which would not otherwise have been committed in order to establish the fact of the crime, i.e., to obtain evidence of its commission and to initiate criminal prosecution [11]. "The key question is who formed the intent of the person. If it is proved that the person's intent to commit a crime arose on its own, and he simply reacted to it in time, then there is no provocation. And yet, in order to take any active action, law enforcement officers need to have objective information about the preparation for the crime" [12].

In decision "Teixeira de Castro v. Portugal", the ECtHR set his opinion on additional persons (undercover agents), that were involved in the control of the crime: "the use of undercover agents should be limited and guaranteed. It is not in the public interest to justify the use of evidence obtained by inciting such activities by law enforcement officers. If the actions of undercover agents motivated a person to commit a crime, and there is nothing to suggest that it would have been committed without this intervention, then such actions of agents are beyond the permissible and must be determined as a provocation" [13].

The Supreme Court tried to summarize positions of the ECtHR on that issue and in one of its decisions noted that "in accordance with the requirements of the ECtHR to distinguish provocation from the permissible behaviour of law enforcement agencies, some criteria must be met. The substantive criterion means the presence/absence of significant substantive features 
inherent in the provocation of law enforcement agencies, and the procedural criterion means the presence in court of the ability to verify information about the alleged provocations during the hearing" [14].

In some cases, the ECtHR recognize lawful actions of law enforcement agencies in usage of undercover officers (agents) at the stage of preparation and commission of a crime. For example, in decision "Bykov v. Russia" [15] the ECtHR acknowledged that the "killer" was an undercover officer (agent) who used a radio microphone to record a conversation with the person who ordered the murder. The ECtHR ruled that the applicant was in a comfortable environment, and that the "killer" was not pressured, he was free to speak about the circumstances of the "committed" crime or not.

The existence of different scientific points of view, as well as the uncertainty and ambiguity of courts decisions in Ukraine and decisions of the ECtHR require further study of the outlined problems.

\section{RESULTS AND DISCUSSION}

According to the practice of the ECtHR and Ukrainian national courts the following list of criteria for distinguishing control over the commission of a crime from provocation could be provided:

1) The crime in any case would have been committed regardless of the intervention of law enforcement agencies or undercover officers (agents).

The key factor in this case will be the establishing of probability of committing a criminal offense without the knowledge of law enforcement agencies. "The nature of pressure or other means of inciting a person to commit a crime is only one of the factors that should be taken into account when deciding whether there is a provocation, but the problem does not end there. To address this issue, a broader context must be taken into account than behaviour of participants during event, which defence considers as a provocation, and prosecution considers as an acceptable method of investigation" [16].

2) Law enforcement agencies became aware of the likelihood of committing a crime after the intent of committing a crime arose in person's mind.

During criminal proceedings it must be established whether there was an objective suspicion that the person was engaged in criminal activity or prone to committing a crime [17]. Any prior information about the existing criminal intent should make it possible to verify this fact [18] and authorities should be able to prove at any time that they had sufficient grounds to carry out a covert operation [17]. "If it is proved that the person's intent to commit a crime arose on their own, and they simply reacted to it in time, then there is no provocation. And yet, in order to take any active action, law enforcement officers need to have objective information about the preparation for the crime" [12].
It should be emphasized that in this case we are not talking about a specific crime, but about probable commission of any criminal offense. For example, if a person is engaged in the illicit sale of drugs, then at the stage of preparation for the control over the commission of the crime, law enforcement agencies should not know the specific buyer, but only the real intention of the person to carry out such activities.

3) Passive behaviour of law enforcement officers or undercover officers (agents).

The ECtHR noted that passive behaviour of authorities cannot be considered when the initiative in contact with the suspect comes from an undercover officer (agent), when the offer is renewed after the initial refusal, when the crime is persistently tempted [19].

Ukrainian judge set his opinion on a person, who was an applicant in criminal proceeding and who transferred money to a suspect as a covert law enforcement officer, was also an applicant or a victim of many other similar cases, which may indicate the "control" of such a person by law enforcement agencies. "The prosecutor's reference that PERSON_4 only repeatedly appealed to law enforcement agencies every time he was demanded funds and in connection with his social position, in my opinion, in no way refutes the defence's reference to provoking a crime against PERSON_1" [20].

4) Strict documentary recording of actions of law enforcement agencies.

"The usage of special methods of investigation cannot by itself violate the human right to a fair trial. The risk of provocation by law enforcement officers caused by these methods means that their use must be strictly regulated. To use such methods, law enforcement agencies must have evidence to support the argument of a person's propensity to commit a crime" [17]. It's important to establish from whom the initiative to commit a crime comes [21].

As it was already mentioned, a person's intent to commit a criminal offense should have arisen before law enforcement officers learned of alleged criminal conduct and began preparing to monitor the commission of the crime. For this purpose, clear procedural recording should take place. Prosecutor will have to provide proof that the intent to commit the crime arose earlier without the active intervention of law enforcement agencies. For example, in the materials of criminal proceedings there should be a statement of the person from whom the bribe is demanded, on the basis of which the control over commission of a crime will be carried out. Or materials of criminal proceedings should contain information obtained promptly about the impending crime, and this information will be used as a basis for the pre-trial investigation. It should be noted that such information will be examined in court, so such evidence must clearly indicate the existence of grounds for monitoring the 
crime, and documentation must be impeccable, because any procedural violations can lead to the recognition of almost all evidence in the relevant criminal proceedings inadmissible according to the theory of "poisoned tree fruit".

It should be emphasized that in case the defence points to the fact of provocation in the process of monitoring [22] the commission of a crime, the burden of proving the absence of provocation rests with the prosecution. "If defendants make allegations of incitement, national courts must consider it in an adversarial, complete, comprehensive and convincing procedure, with the burden of proving the absence of incitement to commit a crime on the part of the prosecution. The scope of the judicial review should include both the reasons for the decision on a certain covert measure, the degree of involvement of law enforcement officers in the commission of the crime, and the nature of any incitement or pressure experienced by the applicant" [23]. "It is the prosecution that must prove the absence of incitement to commit a crime, provided that the defendant's complaints are not entirely implausible" [24].

Accordingly, if law enforcement agencies cannot provide evidence of the absence of provocation, then such actions should be considered illegal. "Materials of the criminal proceeding indicates the need to verify the fact of provocation (incitement) PERSON_1 on the commission of crimes by police officers. The fact of not conducting such an inspection indicates a significant incompleteness of the trial, and the adoption of sentence in such circumstances - a significant violation of the requirements of Criminal Procedure Code of Ukraine" [25].

\section{CONCLUSIONS}

Provocation (in a broad sense) must be identified as a set of measures based on the application of the method of psychological (manipulative) influence on the life of an individual (or groups) in order to achieve appropriate goal.

A provocation over the commission a crime is an action (or inaction) of law enforcement agencies against an individual (or group of persons) in order to influence their decision to commit a crime, provided that the previously mentioned person (persons) did not intend to do so.

In contrast to the provocation, control over its commission could be applied in the presence of following conditions: 1) the crime in any case would be committed regardless of the intervention of law enforcement agencies or undercover officers (agents); 2) law enforcement agencies became aware of the likelihood of committing a crime after the intent of the person who plans to commit it; 3) passive role of law enforcement officers or undercover officers (agents) in committing a crime; 4) strict documentary recording of all actions conducted by law enforcement agencies.

In order to increase the level of efficiency of covert employees (agents) activities to separate control over the commission of a crime from provocation, it is necessary to set strict rules for their possible actions and the conditions of their use in combating specific manifestations of crime.

Activities of all law enforcement agencies of Ukraine require unification of instructions for undercover officers (agents), in compliance with the Law of Ukraine "On State Secrets".

\section{REFERENCES}

[1] Shah Zaib, Muhammad Asif and Maha Arooj (2019), "Development of Aggression Detection Technique in Social Media", International Journal of Information Technology and Computer Science, Vol. 11, №. 5, pp. 40-46. DOI: 10.5815/ijitcs.2019.05.05

[2] Vedomosti, available at: https://www.vedomosti.ru/opinion/articles/2019/07 /19/806842-gde-russkomu-kommentatoru-veselo

[3] Tumski, Stanislav (2017), "Provocation as a social action: phenomenon definition in the context of crossdisciplinary analysis”, Sociodynamics, № 8, pp. 1-11. DOI: 10.25136/2409-7144.2017.8.23349

[4] Dictionary, available at: https://korneslov.info/proishozhdenie-slovaprovokacija/

[5] Zhukov, Igor Mikhaylov, Dmitry, Starikovskiy, Andrey Kuznetsov, Dmitry and Tolstaya, Anastasia (2013), "Security Software Green Head for Mobile Devices Providing Comprehensive Protection from Malware and Illegal Activities of Cyber Criminals", I.J. Computer Network and Information Security, № 5, pp, 1-8. DOI: 10.5815/ijcnis.2013.05.01

[6] Sindhu, K.K. and Meshram, Dr.B.B. (2012), "Digital Forensic Investigation Tools and Procedures", I.J. Computer Network and Information Security, № 4, pp. 39-48. DOI: 10.5815/ijcnis.2012.04.05

[7] Matthew L. Bringer, Christopher A. Chelmecki and Hiroshi Fujinoki (2012), "A Survey: Recent Advances and Future Trends in Honeypot Research", I.J. Computer Network and Information Security, № 10, pp. 63-75. DOI: 10.5815/ijcnis.2012.10.07

[8] Koval chuk, T.I. Korystin, O.Ye. and Svyrydyuk, N.P. (2019), "Hybrid threats in the civil security sector in Ukraine", Nauka i pravooxorona, vol. 3 (45), pp. 69-79. DOI: doi.org/10.36486/np.2019308 
[9] Denson, T.F. (2021), "Breaking the Cycle of Violent Crime and Punishment: The Promise of Neuronormalization", Social Issues and Policy Review, No. 15, pp. 237-276/ DOI: https://doi.org/10.1111/sipr.12076

[10] Land, N. and Sanja Todorović (2020), "Getting to know movement differently: Nurturing communicative, relational, and collective movement pedagogies with toddlers", Journal of Early Childhood Research. DOI: https://doi.org/10.1177/1476718X20969839

[11] The case of Ramanauskas v. Lithuania: ECHR ruling dated (05.02.2008) (complaint No 74420/01), available at: http://echr.coe.int

[12] How to distinguish control over a crime from provocation, available at: https://radako.com. ua/news/ yak-vidrizniti-kontrol-za-vchinennyamzlochinu-vid-provokaciyi

[13] The case of Teixeira de Castro v Portugal: ECHR ruling dated (09.06.1998) (complaint No. 25829/94), available at: http://echr.coe.int.

[14] Provocation of a crime in the practice of the Supreme Court and the European Court of Human Rights, available at: https://equity.law/presscenter/publications/1043.html

[15] The case of Bykov v. Russia: ECHR ruling dated (10.04.2009) (complaint No. 4378/02), available at: http://echr.coe.int.

[16] Opinion of judge Bushenko A.P. (in Ukrainian): Supreme Court ruling dated (11.07.2018) (proceedings No. 51-2645км18), available at: https://reyestr.court.gov.ua/Review/75424564

[17] The case of Bannikova v. Russia: ECHR ruling dated (04.11.2010) (complaint No. 18757/06), available at: http://echr.coe.int
[18] The case of Vanyan v. Russia: ECHR ruling dated (15.12.2005) (complaint No. 53203/99), available at: http://echr.coe.int

[19] The case of Malininas v Lithuania: ECHR ruling dated (01.07.2008) (complaint No. 10071/04), available at: http://echr.coe.int

[20] Opinion of judge Osedacha M.M.: Chernihiv Court of Appeal ruling dated (30.01.2019) (proceedings No. 11-кп/4823/147/19), available at: https://reyestr.court.gov.ua/Review/79629454

[21] Fediunin Anton Evgen'evich and Alferov Vladimir Yur'evich (2017), "Operational experiment and documentation provocation of a bribe or commercial payoff', Bulletin of Moscow University. S. Yu. Witte, No. 1 (10), pp. 41-49.

[22] Mpawe N. Mleke and Mussa Ally Dida (2020), "A Survey of Monitoring and Evaluation Systems for Government Projects in Tanzania: A Case of Health Projects", International Journal of Information Engineering and Electronic Business, Vol. 12, No. 1, pp. 8-18. DOI: 10.5815/ijieeb.2020.01.02

[23] The case of Nosko and Nefedov v Russia: ECHR ruling dated (30.10/2014) (complaint No. 5753/09 and 11789/10), available at: http://echr.coe.int

[24] The case of Matanović v. Croatia: ECHR ruling dated (04.04.2017) (complaint No. 2742/12), available at: http://echr.coe.int

[25] Judgement of Kyiv Court of Appeal (in Ukrainian): ruling dated (19.09.2019) (proceedings No. 11кп/824/2003/2019), available at: https://reyestr.court.gov.ua/Review/84511278 